Justyna OLĘDZKA ${ }^{1}$

\title{
STIMULATING THE HOLDINGISATION OF THE RUSSIAN ECONOMY IN 1991-2008. OUTLINE OF THE PROBLEM
}

Since the beginning of the 90s of the XX century, from a mass of over one hundred and forty million citizens of the Russian Federation only a few created a significant caste which shaped the economic situation, and often also the political one of this country. The process of creating oligarchy is labile, its dynamics correlates with the economic and political situation of Russia, as well as with the results of the global economy ${ }^{2}$.

In all countries of the crumbling communist block, the system transformation meant not only the changes in the area of politics, political culture and mentality of societies, but it was also the time of formation of a new social stratification. In the last decade of the last century, at the junction of the private business - which, in principle, only then began to freely build the modern economy, based on private property and remains of the centrally controlled economy - representatives of the policy and the services of the previous and current system began the process of economic transformation in the ownership sphere ${ }^{3}$.

The capital expansion of oligarchy took place at a loss and for the society, of which $1 / 3$ was plunged into poverty and for the whole political-economic system of Russia. Revolutionary and unfair redistribution of the national wealth was demoralising for the whole class of the representatives of business, but also for a serial citizen of the fallen empire, who sought the only possibility to improve his material status in ambiguous personal systems: nepotism, corruption and cronyism. Political transformation not only did not begin the real generational exchange on the level of government, the personal carousel started in the mid80s gave surprising effects. Party officials very often came to the real wealth only in the Russian Federation.

The Russian country has not kept up with the hasty privatization, which so large scale would not be possible if not for the competence chaos, the lack of systematic changes in the field of economic legislation and the weakness of the just shaping political system. All changes, both in the economy and politics, were top-down decisions. The society was taking the effects of the political decisions as the effect of privatization in the economic field. The

1 Dr Justyna Olędzka, Uniwersytet w Białymstoku.

2 To prove the dynamics of the transformations of this social group we can provide an example of the obsolescence of the popular until recently determination "new Russians" in the journalism and replacing it with another one "new new Russians".

3 B. Durka, 10 lat transformacji rosyjskiej gospodarki [in:] Federacja Rosyjska 1991 2001, ed. J. Adamowski, A. Skrzypek, Warsaw 2002, p. 359; M. Smoleń, Historia Rosji [in:] Rosjoznawstwo. Wprowadzenie do studiów nad Rosją. Podręcznik akademicki, ed. L. Suchanek, Cracow 2004, p. 90 . 
situation was so pathological that the completely strange in terms of culture, legally unregulated, was lobbing, which function was taken over by corruption widespread in Russia.

As characteristic features of oligarchy we should mention: the clan structure and continuous variation of its components. Groups and sub-groups (cliques) within the oligarchy are conducting a constant dispute about the privileges, access to the mass media, the ability to influence power. In particular countries of Central-Eastern Europe the scope of action the generated position of oligarchy are different. By far the strongest and the most prosperous were the oligarchic Russian clans, which have been generated from a broader circle of participants of the economy privatization. In relation to the strong position of the president of the Russian Federation and the weak position of the government and parliament, actions of the oligarchy aimed at the stabilisation of own position, and most of all expanding the area of influences, mainly consisted of the formation of a kind of "court" around B. Yeltsin". The representatives of this clan until the end of the second term of president Yeltsin had such an enormous influence on him so it is difficult to separate which of the actions were the sovereign decision of the head of the state, and which were the result of collective arrangements of coterie ${ }^{5}$.

The strength of Russian oligarchy of the 90 s is the effect of the weakness of the country and the still strong position of bureaucracy, which system transformation has neither been hurt nor altered. Clans were so omnipotent that they replaced the voices of other subjects on the political arena active in the sphere of the broadly understood political culture. Political parties and social movements were the voice created and sponsored by oligarchs and eventually became the instrument of the inter-clan struggles for influence. Similarly, the function of a "tube" of oligarchs was fulfilled by the groups formed within the parliament. Our Home Russia (an examples of "the party of power") was formed as a representative of a group of clans, even before the semi-official takeover of the power by the familia. At the head of the party operating in the years of 1995-2000 stood Viktor Chernomyrdin, a person who was the personification of the essence of the oligarchic system. He was the head of Gazprom, an then the head of the government of the Russian Federation. Provenance of the party leader decided about the shape of the political program (enfranchisement actions as the basis for economic transformations) and the personal compositions (representatives of the nomenclature) of this group. The fate of the group was the projection of the fate of the entire group of the so-called old Kremlin oligarchs. After losing the affection of B. Yeltsin the party had low election results and bad survey records. The threat of marginalization meant this party even though it officially ceased its operation in 2000, has actually revived, this time under the name of the United Russia and the patronage of V. Putin.

In the 90s the power focused on the supportive systems, focused around Kremlin. The impact of the president was based not on the formalised political hinterland, but on the permanent maintenance of the shaky balance between different groups of interest and pressure. The president was dependent on the native financial oligarchy, which torpedoed all attempts to reform the economy. This resulted in the real depreciation of the presidency and the crisis of functioning of other power structures. As a result of the weakening of the government, the power focused in the hands of the president's entourage. As a result, the democratic transformation of the 90 s proved to be incomplete and inconsistent.

4 G. Przebinda, Piekło z widokiem na niebo, Cracow 2004, p. 18.

5 Unofficial decision-making structures in Russia (see I. Topolski, Sita militarna w polityce zagranicznej Federacji Rosyjskiej, Lublin 2004, p. 37). 
V. Putin used the motto of moving the oligarchs from power in order to move the group of businessmen, with informal influence, from the political sphere and the acquisition of the wealth often illegally accumulated by them in the strategic areas of the state (mainly raw material, machine and financial) ${ }^{6}$. Ignoring the warnings of the president from engaging in the affairs of the Kremlin, Boris Berezovsky and Vladimir Gusinsky criticised in their media the policy of the head of the state, in particular with regard to Chechnya. They have also burdened the president with responsibility for the sinking of Kursk. V. Putin has then used the authority to limit their political influence and take a part of the wealth.

A typical measure in the fight against the oligarchs were the allegations of a financial nature. The result of the campaign against the oligarchs was for the Kremlin to recover the estates, or to gain control of the estates of the oligarchs, and consequently depriving them of their political ambitions, and even forcing them into exile. After the emigration of B. Berezowsky and W. Gusinsky from Russia, the only oligarch manifesting political ambitions was Mikhail Khodorkovsky. Initially, V. Putin had good relations with M. Khodorkovsky. Before the election to the Duma in 2003, the oligarchs began the efforts to maintain their influences. M. Khodorkovsky has then changed the course and started supporting the opposition parties. The political activity of M. Khodorkovsky exceeded the business lobbying and due to the financial possibilities of the head of Yukos, it was received in the Kremlin as an attempt to create a strong opposition to the government. The oligarch did not hide the ambition to take part in the presidential elections in 2008 . V. Putin used the trial with him to confirm his power in the country. He did it even though there was a risk that the freezing of assets of Yukos can lead to the increased concern in the West and the decline of trust to Russia. The case of M. Khodorkovsky has brought several advantages to the Kremlin: elimination of the influential oligarch with great political ambitions, strengthening of the position of Rosneft and oligarchs have received a clear message from the Kremlin - either political ambitions or the security of interests.

The Yeltsin familia was the symbol of the moral decay. It was also the embodiment of the downfall of the state and economy, and the political and human weakness of the president. It included, among others: Roman Abramovich, Aleksandr Voloshin, Viktor Jumaszew, Tatiana Diaczenko, Vladimir Potanin, Vladimir Gusinsky. In reality, the familia was create by two oligarchic clans: Anatoly Chubais and Boris Berezovsky, which instead of fighting each other, have intensified their efforts in order to multiply their fortunes and political influence. In view of the political and health weakness of president Yeltsin, in the focus of the interest of the Kremlin familia was the president's daughter - T. Diaczenko. For a long time she was a close associate of the most known oligarch of the 90s, B. Berezovsky, the media tycoon (the owner of, among others, television: ORT, TW - 6 magazines: „Kommiersant”, „Niezawisimaja gazieta”, „Nowyje Izwiestja”, „Ogoniok”). B. Berezovsky was a prominent figure not only among the business circles. He has also started his political career. From 29.10.1996 to 5.11.1997 the deputy of the Security Council of the Russian Federation responsible for the regulation of the Chechen crisis; from 29.04.1998 to 4 March 1999 the executive secretary of the Commonwealth of the Independent States. The position of B. Berezovsky in the structures of power did not reflect his real impact on the political decisions of $\mathrm{B}$. Yeltsin, whose collapse also meant the end of one of the most

6 On 25 February 2000, the press published the "Open letter of Vladimir Putin to Russian voters" the announcement to condemn the clans and oligarchs in the structures of power at the regional and federal level; http://www.putin2000.ru/ (access: 15.07.2010). 
spectacular career of the transformation years. In reality, familia came to real power at the end of the Boris Yeltsin era, and the early 90s have formed much more affluent clans operating on huge areas of the Russian territory. Unquestionably the strongest clan, also known as the oil-gas lobby, is signed with the names of Viktor Chernomyrdin and Rem Wiachiriew. Gazprom is the company, which gave and gives unimaginable influences, sometimes is a springboard to the political career, or possibly the shelter at the end of this career (e.g. in the case of W. Chernomyrdin ${ }^{7}, \mathrm{R}$. Wiachiriew ${ }^{8}$, Viktor Zubkov ${ }^{9}$ ). The struggle for influence with the oil-gas clan was conducted by a group of siloviki, symbolised by the trinity: Korżakow - Barsukow - Soskowiec ${ }^{10}$. They have lost the rivalry mainly due to the lobby for the conduct of the Chechen war, which in consequence led to delegitimize of the leadership of B. Yeltsin. Territorially limited clans were groups led by Yuri Luzhkov (near Moscow), A. Czubais (the group of "Petersburg liberals", which later became the backbone of "Petersburg economists"), regional clans - Murtaz Rakhimov (Bashkortostan), Mintimer Szamijew (Tatarstan), Kirsan Ilmużynowa (Buryatia), Eduard Rossel (Urals).

B. Yeltsin was offered the access to own media and accounts by the oligarchs. In return, they wanted to maintain the status quo and resign from announcing the state of emergency. This was dictated by no means by the concern of oligarchs about the institution of democratic elections, but most of all there was fear about the destruction of the perfect symbiosis of bureaucracy and business. Media activities of clans proved to be so effective that B. Yeltsin, beginning the presidential campaign with the support of 2-3\%, won the presidential election in 1996. This election marketing miracle and proof of extraordinary abilities of the election campaign manager A. Chubais was, however, extremely expensive for the Russian state $^{11}$. The next stage of privatization and distribution of state posts has began. For example, the head of the company Interros W. Potanin became the deputy, Sergei Kiriyenko under pressure from the oil lobby became the Prime Minister. The Russian society definitely contested the behaviours of the Kremlin "court", the citizens impoverished, and the speculators and millionaires multiplied their wealth. The economic crisis was blamed by the Russians on Yeltsin and his entourage, this group was thought to be the instigators of the economic collapse, who once again were trying to enlarge the fortunes at the expense of the Russian state ${ }^{12}$. In fact, the real power of B. Yeltsin was then very modest, and his transaction of posting the actual part of power was forced by a difficult situation during the election campaign in 1996. As a result, the symbiosis of power and business was the essential ele-

7 Vice President, twice Prime Minister of Russia, the minister of the oil industry of the USSR, as well as the head of the board of Gazprom.

8 Deputy Minister of the USSR gas industry, then Gazprom, R. Wiachiriew, former president of Gazprom, adviser of D. Medvedev, then the deputy of the head of the administration of President Putin.

9 The fist Deputy Prime Minister of Russia, at the end of his political career, the president of the Boards of Directors of Gazprom.

${ }^{10}$ Until 1996 in the composition of the presidential administration.

${ }^{11}$ According to W. Panuszkin in exchange for support of B. Yeltsin, the Kremlin promised the privatization of oil wells and metallurgical plants, for W. Paniuszkin, Michait Chodorkowski. Więzień ciszy, Warsaw 2006, p. 53.

12 Ibid, p. 51. 
ments leading to the erosion of the legitimacy of the presidential authority ${ }^{13}$. The president was disregarded, he became a controllable person and his health has seriously deteriorated.

B. Yeltsin became the political hostage of oligarchs primarily because of their almost unlimited possibilities to create the media reality. Democratization of media and their privatization as a result led to the paradoxical situation of limiting the democratically legitimised power and its dependence on the representatives of the private business. President Yeltsin's achievements as the architect of the system transformation were overshadowed by his ambiguous behaviours towards the oligarchic clans, chaotically and rapidly accumulating all companies present in the economic arena of the country. His susceptibility to the oligarchy claims made the term "privatization process" in Russia gain a pejorative meaning. The erosion of the legitimacy of the state power was directly proportional to the rate of enrichment of the group of oligarchs and irretrievably deprived Yeltsin of opportunities for the reconstruction of authority in the society.

V. Putin in contrast to B. Yeltsin was not a hostage of oligarchy. He did not owe it any significant commitments during the election campaign. It should be added that the election campaign conducted by him, as well as its political and election context significantly differed from the situation, in which B. Yeltsin had to fight for the election. The oligarchic structure shaping the elements of the legitimacy process of the first term of V. Putin consisted of the inherited from B. Yeltsin "Old Kremlin clan - familia", the clan of Luzhkov and the "Old Petersburg clan", was supplemented with the "New Petersburg" clan. Each of these groups had a wide impact of influence on the political arena, starting from the influences in the Duma up to own political parties.

The initial stage of the operation "Successor" did not proclaim the clans with the change of the Kremlin policy towards them, because V. Putin was a person from the circles of B. Yeltsin and "familia". He collaborated with oligarchs, was also their client - B. Berezovsky conducted a campaign promoting V. Putin aired on ORT in 1999/2000. Strengthening the position of V. Putin has led to the open conflict with representatives of the old oligarchy. For V. Putin they were a great threat because of the existing media assets. Heirloom after B. Yeltsin began to burden V. Putin, and the confrontation with representatives of oligarchy was inevitable, but also risky. The open criticism of V. Putin's actions in media of B. Berezovsky and W. Gusiński forced the moderators of the "succession" operation to come against the recent allies and partners. After winning the election in $2000 \mathrm{~m}$ V. Putin took a much tougher stance against the oligarchs ${ }^{14}$. Also M. Khodorkovsky fell in disfavour, who began to compete with the Kremlin politically, granting financial support to the greatest opposition factions in the Duma. He sponsored, among others, opposition parties of Yabloko and SPS. He was arrested on charges of fraud and evasion of taxes, and the arrest was preceded by a massive media campaign against this oligarch and a series of tax audits in the foundation "Open Russia" and organizations cooperating

1313 most powerful oligarchs of Russia in fear of communists united the efforts, the campaign was supported by the avalanche of money, American specialists from the election campaigns in the USA: R. Dresner, S. Moore, G. Hormon, J. Schumate.

${ }^{14}$ In May 2003, the National Strategic Council directed by the political scientist S. Biełkowski published a report "The country and oligarchy", which talks about the fact that the great business in Russia has too much power, see W. Paniuszkin, op. cit., p. 145. 
with $\mathrm{it}^{15}$. In reality, M. Khodorkovsky was the only representative of the old oligarchy, who had the personal potential to create a real competition for V. Putin. For political ambitions sanctions were issued to M. Khodorkovsky and his associate P. Lebedev of penalty of 9 years of imprisonment, and in 2009 the prosecutor once again reiterated the allegations ${ }^{16}$. The case of M. Khodorkovsky, recognized by AI as a political prisoner could prove dangerous for Putting for two reasons. His international positions as a result of critical attacks of the organisations fighting for human rights, potential diplomatic notes of the selected countries, condemning the use in the democratic regime, solutions typical for non-democratic systems could be reduced. Second, threatening for the Russian economy could be the negative reactions of companies with foreign capital, including the pacification of branches of foreign companies, or the withdrawal of assets. Nothing like that has taken place, what clearly confirmed that in the new political reality the oligarchy ceased to be a major player, creating the socio-political reality for other forms of social and economic activities. It also seems that for many years the oligarchy will be the party striving for the integrity of the developed consensus, because the penalty for breaking the established framework of cooperation has proven to be purely communist in the form and content.

B. Berezovsky elected in 1999 to the Duma, protesting against the authoritarian policies of president Putin a half year later renounced his mandate and began public anti-Putin protests, and then engaged in the creation of the Liberal Russia, a democratic and liberal party, opposition to the Kremlin ${ }^{17}$. Since 2001 he has lived on the "political exile" in Great Britain, in fact he has been saved most of all by the necessity to counter the prosecution claims about the fraud. The Prosecutor's Office continues to strive for extradition, in 2006 the General Prosecutor's Office of Russia initiated a new proceeding against him (allegations: plans to seize the power in the Russian Federation), and in 2007 the court issued a default judgment on him (six years of work in the colony). The specific immunity was also taken away from W. Gusiński, the owner of a powerful holding Media - Most, who after the conflict with V. Putin in 2000 was arrested for a few days. Then, he moved to Spain, where he was arrested based on the international arrest warrant. Released on bail he is the object of extradition of the Russian Prosecutor's Office, and some of his assets (including shares of companies belonging to Media - Most) were claimed in the settlement for the financial commitment to Gazprom. There are also opinions that they were the price of W. Gusiński for the opportunity to leave the Russian Federation.

Unquestionably, oligarchy after the departure of B. Yeltsin has been striped of its political and economic status. The extensive propaganda action has begun in favour of the "equal distance of oligarchs from power", and the popularity of this slogan has significantly improved V. Putin's results of the popularity polls. Initially, the presidential plan to fight with the oligarchy was even more radical. Because it assumed the settlement of the results of privatization of the $90 \mathrm{~s}$. Fighting with the ones getting rich on the unfair privatization was not the populist slogan, but the carrier ${ }^{18}$. In fact, because of that it was possible to fight with

${ }^{15}$ On 24 February 2005, the Federal Tax Service started the next control in the established and directed by M. Khodorovsky foundation "Open Russia" and in the cooperating with it 23 partner organisations.

16 A new process of M. Khodorkovsky, began on 3 March, 2009.

17 A. Głowacki, A. Stępień Kuczyńska, Rosja Putina, Lodz 2008, p. 264.

${ }^{18}$ I. Wiśniewska, Niewidzialna ręka... Kremla. Kapitalizm państwowy po rosyjsku, OSW Viewpoint no. 14, Warsaw, February 2007, p. 5. 
the political opponents of all orientations, control the opposition and build in the media the image of the honest president. The oligarchs no longer constituting the autonomous political power reduced the plans of participation in the shaping of the political scene. The end of careers of two giants of the media industry was the beginning the a new agreement of $\mathrm{V}$. Putin with oligarchs ${ }^{19}$. The guiding principle shaping these relations was that the essence of the oligarchic system remained unchanged, and the declared separation of the country and business remained only in the declarative sphere. Restrictive activities involved mostly oligarchs closely associated with B. Yeltsin, but not all of them ${ }^{20}$. Some of them managed to more or less maintain the position and assets (Mikhail Fridman, Oleg Deripaska, Viktor Wekselberg, Aleksiej Mordaszow, Vladimir Potanin). Significant is an example of R. Abramovich, the former partner of B. Berezovsky, who in the years 2000-2008 became the Governor of the Chukotka Autonomous District, but against his numerous investments, performing this function seems a bit exotic ${ }^{21}$. In 2001 he spent from his own funds 18 million dollars to improve the living conditions of the inhabitants of Chukotka. The true test of his loyalty towards the new head of the Kremlin was in 2005 the sale of Sibnieft to Gazprom. This is an example of re-nationalization of the company from the oil industry.

Loyalty of oligarchs appreciated by V. Putin gave tangible results. Because the president has often made public declarations to stop the studying of the privatization processes of the past years and abandonment of the revision of their results ${ }^{22}$. A consensus satisfactory for both parties resulted in, among others, the formation of the "lobbyists club" in place of the Federation Council, that is the oligarchic-governor effect of the staff policy (almost 1/3 of the Federation Council are the managers of private companies ${ }^{23}$. Oligarchy (cautiously) not focused around the Kremlin (outside the groups closely related to V. Putin), and to moved its activity the outskirts of the country, e.g., to Yakutia, Ewenkia. Was the "process of regionalization of interests of financial groups".

\section{CONCLUSIONS}

Transformation of oligarchy of the times of V. Putin is definitely noticeable. The strategies of industrial-financial groups is different, they become the specialized units with the precise profile of action - different from the holdings of the $90 \mathrm{~s}$, in which all companies were present, which were profitably possessed, regardless of the industry in which they operated. Also their actions are different, these groups do not search for tax reliefs or special privileges, but aim for the system changes, comprehensive changes of the tax legislation, customs, or the reforms of the principles of managing the natural monopolies ${ }^{24}$. Unquestionably, oligarchs show the full willingness to cooperate with the transformation

19 A. Dubas, J. Rogoża, I. Wiśniewska, Rosja w kryzysie: rok pierwszy, OSW Report 2010.01.27, p. 29.

20 E.g. Russnieft' changed the owner: 30 July 2007 M. Gucerijew, president and the main shareholder (7. in terms of the size of extraction, the Russian oil company), announced that he withdraws from the business.

21 A. Głowacki, A. Stępień Kuczyńska, op. cit., p. 263.

22 On 16 November in the speech, V. Putin had to ensure the integrity of the results of privatization and protection of private property.

${ }^{23}$ E. Paszyc, I. Wiśniewska, Wielki biznes w rosyjskiej gospodarce i polityce za rzadów Putina, The „CES Studies”, p. 13.

${ }^{24}$ E. Paszyc, I. Wiśniewska, op. cit., p.5. 
processes of the media, adapting their activity to the Kremlin requirements (guidelines of the Kremlin strategists of the political communication and creators of election technologies) and thus guaranteeing the required information and personnel policies at the price of the possibilities to act in the economic sphere ${ }^{25}$.

Around the person of V. Putin gathered the elite with the non-Moscow provenance, and the crisis of 1998 and the change of the president allowed to redistribute and renationalisation of the most attractive assets. These phenomena conditioned the broadening of the amount of assets, held by the ruling elite, and consequently strengthening the role of Putin as a manager and an arbitrator of this environment ${ }^{26}$. The composition of the new oligarchy includes, among others, Giennadij Timczenko ${ }^{27}$, Yuri Kowalczuk, Sergei Furskienko ${ }^{28}$, Sergei Czemizow, Igor Sieczin (wicepremier), Vladimir Jakunin ${ }^{29}$. President Putin pursued a policy of strengthening the country in the economy, what has yielded most of all in the significant improvement of the condition of the state holdings and weakening of the position of the private business, struggling with the economic problems, being the effect of the global crisis. It should be assed that the foreign expansion of the foreign capital has not been halted.

V. Putin made the reconstruction of the hierarchy of power, put an end to the supremacy of regional elites and local barons - governors and presidents of autonomous republics. The establishment of seven federal circuits and pacing at their heads the representatives of the president allowed Russia to introduce the common legal space and adapt the local regulations to the federal law. He has successfully introduced the elite of the regional power into the area of the central power elite. Actions in the sphere of politics resulted in the activity in the sphere of property. It is the Kremlin that decides today about the vectors of activity of entrepreneurs and the way of the distribution of goods.

\section{REFERENCES}

[1] Dubas A., Rogoża J., Wiśniewska I., Rosja w kryzysie: rok pierwszy, OSW Report, 27.01.2010.

[2] Durka B., 10 lat transformacji rosyjskiej gospodarki [in:] Federacja Rosyjska 1991-2001, ed. J. Adamowski, A. Skrzypek, Warsaw 2002.

[3] Federacja Rosyjska 1991-2001, ed. J. Adamowski, S. Skrzypek, Warsaw 2002.

[4] Głowacki A., Stępień-Kuczyńska A., Rosja Putina, Lodz 2008.

[5] Furier A., Dekada Jelcyna, Szczecin 2003.

[6] Paszyc E., Wiśniewska I., Wielki biznes w rosyjskiej gospodarce i polityce za rządów Putina, The „CES Studies”.

[7] Rogoża J., Władzy raz zdobytej nie oddamy nigdy. Rosyjska elita władzy wobec sukcesji $i$ kryzysu gospodarczego, OSW works, October 2009, p. 8.

\footnotetext{
${ }^{25}$ Examples could be multiplied, see the example of the editor ",Izwiestia” of R. Szakirow.

${ }^{26}$ K. Kurczab-Redlich, Gtowa o mur Kremla, Warsaw 2007, p.58.

${ }^{27}$ Rapid expansion of companies controlled by G. Timchenko.

${ }^{28}$ J. Rogoża, Władzy raz zdobytej nie oddamy nigdy. Rosyjska elita władzy wobec sukcesji i kryzysu gospodarczego, OSW works, October 2009, p. 8.

29 A. Dubas, J. Rogoża, I. Wiśniewska, Rosja w kryzysie: rok pierwszy, OSW Report, 2010.01.27, p. 29.
} 
[8] Wiśniewska I., Niewidzialna ręka... Kremla. Kapitalizm państwowy po rosyjsku, OSW Viewpoint no. 14, Warsaw, February 2007.

\section{STYMULOWANIE HOLDINGIZACJI ROSYJSKIEJ GOSPODARKI W LATACH 1991-2008. ZARYS PROBLEMU}

We wszystkich państwach rozpadającego się na początku lat 90. XX wieku bloku komunistycznego, transformacja systemowa oznaczała nie tylko zmiany w sferze polityki, kultury politycznej i mentalności społeczeństw - był to również czas tworzenia się nowej stratyfikacji społecznej. W Rosji, na styku prywatnego biznesu i państwa powstała grupa oligarchów, bez skrępowania wykorzystujących typowy dla transformujących się systemów symbiotyczny splot: uwolnioną gospodarkę, opartą na własności prywatnej oraz pozostałości gospodarki centralnie sterowanej. Przedstawiciele elity władzy i elity biznesu rozpoczęli proces przekształceń gospodarczych w sferze własności. Pozycja oligarchii w rosyjskim systemie politycznym była kluczowa dla legitymizacji przywództwa państwowego w latach 19912008. Pozycja prezydenta oparta była bowiem nie o sformalizowane zaplecze polityczne, kluczowe było utrzymywanie chwiejnej równowagi między różnymi grupami interesu i nacisku. Instytucja prezydenta została na wiele lat osłabiona i uzależniona od wpływów oligarchii.

Słowa kluczowe: oligarchia, transformacja gospodarcza i polityczna, Federacja Rosyjska.

DOI:10.7862/rz.2017.hss.31

Przestano do redakcji: luty $2017 \mathrm{r}$. Przyjęto do druku: czerwiec 2017 r. 
